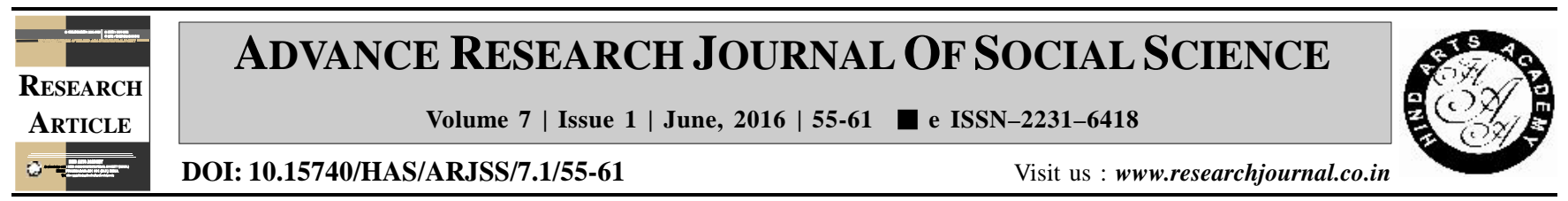

\title{
A socio-economic analysis of women's participation in sericulture
}

S. Raveesha*, K. Amaresh Kumar ${ }^{1}$ and D. Shashikala Bai ${ }^{2}$

Department of Agricultural Economics, College of Horticulture, Hiriyur, CHITRADURGA (KARNATAKA) INDIA

${ }^{1}$ Department of Agricultural Extension, College of Horticulture, Hiriyur, CHITRADURGA (KARNATAKA) INDIA

${ }^{2}$ Department of Agricultural Engineering, College of Horticulture, Hiriyur, CHITRADURGA (KARNATAKA) INDIA

\section{ARTICLE INFO :}

$\begin{array}{lll}\text { Received } & : & 22.02 .2016 \\ \text { Revised } & : & 06.04 .2016 \\ \text { Accepted } & : & 11.05 .2016\end{array}$

KEY WORDS :

Women, Sericulture, Economic analysis, Sericulture, SWOT

HOW TO CITE THIS ARTICLE :

Raveesha, S., Kumar, K. Amaresh and Bai, D. Shashikala (2016). A socioeconomic analysis of women's participation in sericulture. Adv. Res. J. Soc. Sci., 7 (1) : 55-61, DOI: 10.15740/ HAS/ARJSS/7.1/55-61.

*Author for correspondence

\section{ABSTRACT}

Silk is one of the most commercially and traditionally valued product in the world. It not only provides livelihood but also creates employment opportunities for millions of people. Women's income plays a dominant role for food, financial and educational upliftment of the rural families. Mulberry is one of the major commercial crop for majority of dry land farmers in India particularly in Karnataka. This study aims to understand the participation of women in sericulture and to know the problems faced by them. The rural women entrepreneurs engaged in Sericulture activities along with agriculture in old Mysore, Tumkur, Chikkaballapur and Kolar districts of Karnataka were selected for the study. The respondents were randomly selected a total of 120 (30 from each district) respondents. Simple statistical tools like averages and percentage distribution has been used to analyse the data, in order to draw meaningful inferences and to facilitate comparison of the average farm situation. Majority of respondents (60 $\%)$ are engaged in sericulture, it contributes the highest percentage $(28.41 \%)$ of the income of the households, followed by service sector contributing 20.32 per cent. Involvement of women is high in all activities except those activities which involve going out from their homes like collection of planting material and procurement of fertilizers and manure. This study indicated that 25.83 per cent of respondents started sericulture to do as an independent business followed by 23.33 per cent have increased their economic status, 22.50 per cent of the respondents are earning high net income and 19.16 per cent have felt that it is suitable for small farmers. The study indicates that Sericulture can come out as the most vital opening, in generating women's income in rural areas. Most of the women entrepreneurs involved in sericulture have minimum educational qualification, so government and sericulture department can organize effective training and development activities along with the line departments to uplift socio-economic status of the rural women's. 